\title{
AgriBusiness versus AgriCulture
}

\author{
Jack Trevors • Milton Saier
}

Published online: 6 June 2007

(C) Springer Science + Business Media B.V. 2007

Eat a sunbeam for breakfast, the wind for your lunch, and a moonbeam for dinner. Only then will you prosper - non-destructively.

Man diverged from the chimps 6-7 million years ago, but human culture is a much more recent development. It has been argued that the advent of agriculture, the agricultural revolution, was the greatest advance made by mankind - greater than any of our current scientific and artistic advances. Why? Because it freed humans from a nomadic hunter-gatherer existence, which required a full time effort for survival. Before the agricultural revolution in about 8,000 B.C., there was little free time to dream, create and invent. Indeed, it was seldom possible to stay put for more than short periods of time. People had to follow available sources of food and water. But this advance had its down side.

Even when the human population was relatively small, some 2,000-4,000 years ago, agricultural practices were already causing damage to the biosphere. The increased flow of silt and minerals into the oceans, caused the first human-promoted coral bleaching, long before the development of modern

J. Trevors $\cdot$ M. Saier $(\bowtie)$

Division of Biological Sciences (0116),

University of California, San Diego,

La Jolla, CA 92093-0116, USA

e-mail: saier@biomail.ucsd.edu technologies. But the industrial revolution, just 200 years ago, introduced new forms of pollution and enhanced the degrees of pre-existing pollution by several orders of magnitude. Only then, with the human population in exponential growth, did the damage become extensive.

At this point, I would like to introduce two contrasting terms first introduced to me by Professor Jack Paxton: agriculture and agribusiness. Agribusiness is defined as corporate farming and ranching, promoted by the use of farm machinery, fertilizers and genetically modified crops, and involving huge tracts of land owned and operated by large corporations. The food produced is used for global purposes and is transported hundreds or even thousands of miles. The average distance our food is transported to us is estimated to be about 1,500 miles.

Agriculture, on the other hand, is defined as smallscale farming, often organic, where emphasis is placed on consumption of locally raised crops produced using manpower, natural soil nutrients, nitrogen fixing microorganisms, and crops of diverse natural genetic backgrounds, rotated over the years. The latter are produced for the nearby communities, minimizing transportation costs, fossil fuel consumption, pesticide pollution and greenhouse gas production.

Agribusiness tends to obliterate ecosystems for several reasons. First, land destined for agribusiness purposes is completely modified; native plants are 
killed, invasive species are introduced, the soil is plowed, wetlands are drained and grasslands are grazed. Second, water is added or withdrawn which can change whole ecosystems, and if transported distances, or derived from underground sources, that water is often more saline than are local sources. This will increase the soil salinity, reducing the growth of certain crops. Third, instead of natural sources of nutrition, chemically generated fertilizers from far away are used in large quantities. These flow into rivers, lakes and the sea, causing algal and bacterial blooms (eutrophication) accompanied by oxygen depletion and fish kills. Fourth, large-scale agribusiness causes tremendous pollution not only due to the use of fertilizers but also of pesticides of all types (herbicides, antibiotics, fungicides, etc.). Meat production is particularly polluting, creating greenhouse gas pollution as well as massive amounts of excrement, always a problem when animals are raised under crowded conditions. Finally, agribusiness, in contrast to agriculture, depends on a large source of cheap labor which in this country is often provided by poor economic slaves. As Jack Paxton likes to emphasize, while small-scale agriculture can be referred to as "farming," agribusiness can be thought of as P-HARMing! Unfortunately, agribusiness is not restricted to food production. It involves growing cotton, hay, timber, tobacco, flowers and ornamental plants. Tremendous amounts of resources are also consumed supporting companion animals such as dogs, cats and horses.

While food is important for us all (we would last only a few weeks without it), even more important is air and water. We would survive only a few minutes without air and only a few days without water! The quality of our air and water must be good in order to support healthy life. While most of the water for San Diego comes 200-300 miles from the Colorado River, it must be diluted with water coming over 700 miles from Northern California sources to reduce contaminating salts and pollutants down to acceptable public health levels. Pollutants in our air and water decrease lung capacity and cause cancer, especially in infants and young children.
Most of the California water supply has traditionally been used for farming, but with our burgeoning population, more and more must be diverted for urban use. San Diego is now buying water from farms. As Dr. Paxton points out, farmers buy water from the Colorado River for $\$ 17.50$ per acre foot and sell it to the city for $\$ 275 /$ acre foot! Talk about a cash crop!

California is the largest agribusiness in the nation, producing $11 \%$ of the nation's produce. In fact, California's Central Valley produces about $25 \%$ of the nation's table food. In the past, much of this agribusiness was supported by underground water sources. But when this water is removed, the land sinks, a process called subsidence. Subsidence has affected over 5,000 square miles in the San Joaquin Valley. The maximum subsidence, near Mendota was $28 \mathrm{ft}$ between 1925 and 1977! And subsidence is irreversible! For bad or for worse, subsidence won't occur much more in this area because much of the groundwater is already gone. New sources are sought for agribusiness to continue.

How can the HARM in P-HARMing be reversed? Many people are convinced that the solution lies in community supported agriculture - use of local gardens and family farms growing organic products for local consumers. Using more hemp products, and consuming lower on the food chain would also be of benefit. Eliminating farm subsidies, over $80 \%$ of which goes to the largest food-producing corporations, would help. While family farmers have played a major role in the past, they are not the recipients of most governmental subsidies. Agribusiness has a powerful lobby in Washington, and it pays off!

It is estimated that we Americans waste over $\$ 10$ billion worth of prepared foods per year. Some of this is a result of agribusiness efforts. No other country in the world wastes as much as do Americans, even on a per capita basis. Using food products more efficiently would help us achieve sustainability. And sustainability is the key we must strive for in order to maintain a world that can be enjoyed by our children, their children, and the generations that will follow. 